\title{
Paradoxes in psychology resonating in its empirical research of religion
}

\section{Continuing dialogue with Ralph W. Hood}

\author{
Jacob A. Belzen
}

Received: 14 December 2020 / Accepted: 4 January 2021 / Published online: 3 February 2021 (C) The Author(s) 2021

\begin{abstract}
As a scientific enterprise, the psychology of religion is vitally dependent on developments in psychology in general, sharing its strengths as well as its weaknesses. The article discusses psychology being haunted by a number of paradoxes that resonate in psychological research on religion as well. As a prominent specimen of such empirical psychology of religion, the oeuvre of R. W. Hood, a wellknown contemporary US contributor to that field, is selected. Another stage in a long-standing cheerful dialogue with Hood, the article points out some remarkable parallels with the oeuvres of Hall and James, founding fathers of US psychology. While critically engaging with some of the core issues and tendencies in Hood's publications, the article explains the sense in which his struggle to find a balance with regard to three paradoxical tendencies will be a major task for the field during the next few decades of the 21 st century.
\end{abstract}

Keywords Psychology of religion · Unity $\cdot$ Progress $\cdot$ Relevance $\cdot$ Methodological agnosticism 


\section{Paradoxe in der Psychologie und ihre Resonanz in deren empirischen Religionsforschung}

Nächster Schritt im Dialog mit Ralph W. Hood

Zusammenfassung Als wissenschaftliches Unternehmen hängt die Religionspsychologie entscheidend von den Entwicklungen in der Psychologie im Allgemeinen ab, teilt jedoch neben deren Stärken auch ihre Schwächen. Der Beitrag diskutiert die Psychologie als von einer Reihe von Paradoxien heimgesucht, die ihre Resonanz in der psychologischen Religionsforschung haben. Als herausragendes Beispiel für die empirische Religionspsychologie wird das Werk von R. W. Hood ausgewählt, einem bekannten zeitgenössischen US-amerikanischen Autor auf diesem Gebiet. Als weiterer Schritt in einem langjährigen heiteren Dialog mit Hood, weist der Beitrag hin auf einige bemerkenswerte Parallelen zu den Werken von Hall und James, Gründervätern der US-amerikanischen Psychologie. Einige der Kernthemen und Tendenzen in Hoods Veröffentlichungen kritisch aufgreifend, erklärt der Beitrag in welchem Sinne sein Bemühen drei paradoxe Tendenzen in den Griff zu bekommen, in den nächsten Jahrzehnten des 21. Jahrhunderts eine Hauptaufgabe für das ganze Fachgebiet sein wird.

Schlüsselwörter Religionspsychologie · Einheit · Fortschritt · Relevanz · Methodologischer Agnostizismus

\section{Paradoxes de la psychologie résonnant dans sa recherche empirique de la religion}

Poursuite du dialogue avec Ralph W. Hood

Résumé En tant qu'entreprise scientifique, la psychologie de la religion dépend essentiellement des développements de la psychologie en général, mais partage ses faiblesses ainsi que ses forces. L'article traite de la psychologie comme hantée par un certain nombre de paradoxes qui résonnent également dans la recherche psychologique sur la religion. L'œuvre de R. W. Hood, un auteur US-américain contemporain bien connu dans le domaine, est sélectionné comme un exemple exceptionnel de psychologie empirique de la religion. Comme étape supplémentaire dans un dialogue joyeux de longue date avec Hood, l'article souligne quelques parallèles remarquables avec les œuvres de Hall et James, pères fondateurs de la psychologie US-américaine. Reprenant de manière critique certaines des principales questions et tendances des publications de Hood, l'article explique en quel sens son effort pour maîtriser trois tendances paradoxales sera une tâche majeure pour l'ensemble de la psychologie de la religion dans les prochaines décennies du 21e siècle.

Mots clés Psychologie de la religion · Unité $\cdot$ Progrès $\cdot$ Pertinence $\cdot$ Agnosticisme méthodologique 


\section{The course of psychology}

The enterprise commonly referred to as the "psychology of religion" (PoR) is now well over a century old. Although the search for its identity has gradually resulted in some tentative clarity on a number of issues (Saroglou 2020), many of its struggles have proved to be enduring and can be considered as an illustration of much of the course of psychology in general. Paradoxes are abundant in the mother discipline and, logically enough, in the PoR as well. To name just a relatively simple one: until the present day, and despite the efforts of the most prominent colleagues, no unified perspective in psychology has been achieved. The discipline has been expanding enormously, which can not only be explained by the ever-increasing number of phenomena (or entire fields) to which (some) psychology has been applied. It is the everincreasing diversity within the discipline itself, a virtual explosion in approaches, perspectives, and theories that has led to a situation in which no one can still claim to know what is happening in psychology, let alone be able to come up with an uncontested definition of the field. (Paradoxically, discussion and contests often seem to discontinue, not because they are resolved, but because the rivaling factions grow themselves into fields, more or less simply ignoring the others.) Handbooks of psychology in general can no longer tell what psychology "is", but introduce readers to numerous fields that have been successful in presenting themselves as psychology.

PoR being a (small) subdiscipline of psychology in general, this situation is reflected here too. In what, in hindsight, may be considered one of the most important events in the recent history of this subdiscipline, marking the onset of a period of new growth, Spilka et al. (1985) published an impressive stock take of what had been going on in the PoR, finishing with an urgent demand for what they phrased a "need for theory" integrating the many scattered and diverse pieces of empirical research. Several decades later, the same urge is voiced in the fifth edition of what probably remains the best overview of contemporary PoR, an edition more than double the size of the first, covering three times more empirical research (Hood et al. 2018).

Dr. Ralph W. Hood (“jr.", which for decades he kept adding to his name) has been uniquely positioned to come up with statements like these. For about half a century, he has been involved in the PoR, as a commentator, a contributor, and even a steering captain. Diligent and productive like hardly anyone else, he has been promoting the field, also by occupying (and putting his collaborators into) strategic positions: he served prominently with the Religious Research Association and with Division 36 ("psychology of religion") of the American Psychological Association (APA), he helped to re-establish the International Association for Psychology of Religion, he ran or helped to run media such as the Journal for the Scientific Study of Religion, Review of Religious Research, and The International Journal for the Psychology of Religion (IJPR), among others. He can truly be considered a pillar in the field; to many he is the face of the field.

In his oeuvre, a number of the vectors characterizing the PoR are clearly visible. In what follows below, just a few of them can be glimpsed at, by way of hypotheses, as the limited space available does not allow for a thorough analysis. And, as could be expected with someone successfully involved in any field for such a long time, 
neither he nor his work can be easily characterized by employing single labels, not even those of "empiricist" or "psychologist" (although Hood is each of these, he is certainly more than both). Before we continue, however, a personal note may be appropriate here. Over the past few decades, Dr. Hood and I have developed a cordial friendship during which we discussed many issues in the PoR, agreeing on most topics, disagreeing on a few. As these disagreements are by no means personal, but related to core issues in our field, we have brought some of our cheerful dialog out into the open (Belzen 2010a, 2010b; Belzen and Uleyn 1992; Hood 2010; Hood et al. 2016), fair discussion and "joyful science" (Nietzsche 1882/1980)—as special cases of communication so superbly analyzed by Jaspers (1973, pp. 50-107)—having become all too rare in academia. As will become obvious, while applauding much of Hood's effort to tackle some of the problems in contemporary psychology (whether related to the PoR or not), I am also puzzled by some aspects of his work. Although it will be just as obvious that I could be misinterpreting some things, it may be instructive to articulate such impressions as even made on a friendly reader and to discuss some of the fundamental problems in our field. Thus, the present essay constitutes a further step in this long-standing dialog, hopefully provocative enough for Dr. Hood to respond again.

\section{From Hall to Hood}

One of the first to employ the phrase PoR and probably the first to lecture on the subject was G. Stanley Hall (1846-1924), commonly remembered as one of the founding fathers of present-day US psychology. Initially trained as a minister and a philosopher, he developed into an early American advocate of empirical psychology: it was Hall who founded the APA, the world's most influential society for psychology, as well as the first scholarly journal for the new discipline (the American Journal of Psychology). Within the PoR, hardly anyone remembers his name, but here too he can be considered a kind of founding father: Hall was the first to have doctoral students engage in quantitative work in the PoR, and he was the founder of the first journal in this field (the American Journal of Religious Psychology). Although Hall published a good deal, also on the PoR (1882, 1904, 1917), he may have been most important as a driver, a mentor, a networker, and an organizer. In the PoR, he sometimes moved too fast, e.g., when shortly after 1900 he assumed that this new field would be established enough to found a journal specific to it. As there proved to be insufficient material to keep such a journal running, soon the scope and title had to be widened repeatedly, ending up publishing papers that had nothing to do with psychology; some years later the journal had to be discontinued. Although this has been the common fate of all journals and infrastructure in the PoR until recently, it is notable that the IJPR, the journal Hood co-founded in 1991, has continued as the longest regularly published journal for the field today. Nevertheless, Hood sometimes reminds us of Hall, as will be pointed out in a moment.

At the end of the 1960s, Hood's first contributions to the scientific literature were quantitative studies (not just restricted to religion), but this was never his sole interest (Hood 1968). Even before he started publishing on mysticism (a theme for which he 
probably became best known), he presented papers such as "Psychology of religion: the search for appropriate psychological theories" (1973) and ever since he has been commenting on modern psychology (usually in relation to religion), proving himself to be strongly theoretically interested and well-read in psychology of very different provenience. Whereas in general, opposing empirical and theoretical research is a fundamental mistake, in the specific case of Hood it would do no justice to his work to qualify him as an empiricist only, his publications not allowing to reduce him to such. And although his academic degrees clearly qualify him as a psychologist, many people may not be aware how strongly he is rooted in sociology and how much he owes to reading and collaborating with sociologists. (In fact, the "social psychology" program from which Hood graduated was a combination of sociology and psychology, something almost no longer found nowadays (Hood 2012)).

Likewise, the M-scale he developed was not representative of any psychology: what Hood did was try to present empirical support for Stace's (1960) assertion that there is a universal core to all mystical experiences. As tried to argue elsewhere (Belzen 2010a), such a scale cannot provide this kind of support, however, as respondents can only respond to items that presuppose what Stace had asserted. (And whether respondents come from the Americas, Africa or Europe obviously makes no difference.) Any scale starting from the a priori that there is $\mathrm{X}$ will find $\mathrm{X}$, whether administered in the USA, in Iran, the Netherlands or wherever else. To repeat this playfully phrased criticism again: "subjects, wherever on the planet, cannot take out anything else from the magician's hat than what the magician himself has put into it. Any claim by the magician about anything found by anyone in the hat is the result of his having provided the hat in the first place ..." (Belzen 2010b, p. 427.) Stace's (and by consequence Hood's) perennialist assumptions led to fail to account for the instigative and constitutive role of cultural factors in subjects' constructions of experience. There is no need to re-enter this discussion here, but two totally different relevant points about Hood and his work deserve to be made here:

1. The development of the M-scale as such is a specimen of neither psychology nor sociology, but it is a clear effort to engage in empirical research on religion, to apply the method of scale-construction (a technique equally non-specific to psychology and sociology, it can be and is applied by representatives of very different disciplines and adjusted to their goals). Far from being criticism, this point should be understood as a compliment; however, Hood is "not just" doing psychology (or sociology or whatever), he is trying to find out something, regardless of how the effort may be characterized by others, involving a strategy known as radical empiricism.

2. In the course of a discussion about the M-scale, it was pointed out at length that Hood sometimes has a tendency to misrepresent his opponent, even at the level of providing quotations that are nowhere to be found in the opponent's texts (Belzen 2010 b). In a later contribution to this discussion, Hood continues to do so when writing "Belzen is inaccurate when he claims that items were presupposed" (Hood et al. 2016, p. 467). For clearly, it was not this that was said, but rather that the items supposed to verify Stace's items were already themselves based on Stace: a clear case of circular reasoning! Be this as it may, the discussion grants the 
opportunity to compliment Hood again; disagreement and public argument have never prevented mutual respect, collaboration, and friendship (Belzen and Hood 2006; Hood 1997, 2002, 2003, 2012; Hood and Belzen 2005, 2013; Krauss and Hood 2013). Thus, there is no assuming here anything malicious on Hood's part when providing erroneous quotations, on the contrary; but like Hall, he is perhaps doing too much too fast to be always sufficiently precise?

Having established his reputation as an empiricist during the early years of his career (Hood 1968, 1975), Hood proceeded to turn out a number of reflective papers on the PoR (as distinguished from papers reporting psychological research), all the while moving towards empirical research other than the quantitative-statistical type that has come to dominate much of psychology today. Indeed, starting from Hood's work, one could raise quite a number of more fundamental questions: if he is a psychologist of religion (which hardly anyone will doubt), who is he when he is not presenting research in the PoR? Or phrased more generally, who is under which conditions to be regarded as a psychologist of religion?

One should not think that questions like these are without importance: when it comes to, e.g., matters of qualification, employment, or salary, it is highly relevant to know who under which conditions can be regarded as a psychologist! Someone without academic training and/or a license in psychology will probably not be regarded as a psychologist; if at all, under which conditions could such a person be accepted as a psychologist of religion? And on a financially less delicate but academically more complicated scale, we should be aware of the problems Hood et al. have been confronted with when they worked on the consecutive editions of Psychology of religion: an empirical approach: when doing such a major review of psychological research on religion, who and what should be included? Is a publication a psychological study just because an author uses "psychology of religion" in the title? Is anything published by a psychologist eo ipso psychological? The probable answer being negative, we may grant that not everything published by Hood was psychology (nor did it need to be). This issue will deserve some more attention in a moment.

\section{Asking questions: rocking the brand boat? Paradoxes despite production?}

Sometimes, seemingly easy questions require an answer that is not at all easy to give, not even for scientists. In the hurly-burly of everyday life, people often have no time and opportunity for reflection; quick and often superficial knowledge has to suffice, resulting in stereotypes and prejudices, creating opportunities for good and bad journalism, politics, etc. Sometimes people don't even have the opportunity to reflect on questions that, when taking a step back, they would indeed acknowledge to be of basic importance, even in their own daily lives: should I marry this person? How should I raise my children? How should I live? What is good and what is evil? Classically, academia was one of the few places in society where some individuals did take such a step back and reflected, sometimes deeply, on all kinds of questions to 
which answers did not prove to be easy. Sometimes they developed entire theories to answer seemingly easy questions, sometimes ending up with different theories that needed to be ranked according to the probability of their being correct, a procedure about which yet other, so-called meta-theories have been and are being constructed.

At present, however, academia has quantitatively grown in a spectacular way: an enormous percentage of the Western population is being educated and trained at colleges and universities, incredible sums of money are being pumped into research, academia has become big business, with its own hurly-burly, allowing very little space for seemingly simple questions. A very clear example of this trend is the discipline (perhaps one should say: the enterprise) called psychology: the numbers of students turning to this subject are ever increasing (resulting in statements such as "psychology is that discipline most successful in finding its graduates a job", perhaps enviously formulated by someone other than a psychologist). Overlooking an author's more than 50-year involvement, some metatheoretical questions, not only about his work but also about our enterprise, may seem appropriate.

The lack of unity referred to above, which already prompted Karl Bühler (1927) to famously conclude that there is a "crisis in psychology," is not the only paradox that needs to be mentioned when we reflect on this discipline. For the sake of brevity, let us just remember what some qualified commentators on the field have stated repeatedly. On the occasion of the commemoration of Wundt's founding in Leipzig of the first laboratory for experimental psychology (taken by many as the start of modern psychology as such), Henry Gleitman, author of a widely used introduction to psychology, wrote:

I do not know whether we have progressed much beyond [Wundt]. Our techniques are more sophisticated, and there are many more of us, so we can inundate each other in a mass of facts. But much of what we now do and think was already implicit in Wundt, and in other nineteenth century figures. We could do worse than to go back for an occasional glance at our intellectual origins [...] (Gleitman 1985, p. 434).

Likewise, noted psychologist of perception, James Gibson, stated:

The conclusions that can be reached from a century of research on perception are insignificant. The knowledge gained [...] is incoherent. We have no adequate theory of perception, and what we have found in the search for sensations is a mixed batch of illusions, physiological curiosities, and bodily feelings. The implications are discouraging. A fresh start has to be made [...] (Gibson 1985, p. 229-230).

And more recently, when Philip Zimbardo, perhaps the most commonly known US psychologist (thanks to his presence in the media), asked "Does psychology make a significant difference in our lives?", he could only draw on insights developed well before WW II to justify his enthusiastic "yes" (Zimbardo 2004).

The PoR being a part of psychology in general, it hardly comes as a surprise that reflection on this subdiscipline prompted similar judgments about the lack of progress in the PoR. In the Handbook of Social Psychology, Dittes (1969) concluded with regard to the PoR: "publications today are not substantially advanced over the 
earliest writings" (p. 603). Taking a step back, a present-day empirical researcher some 40 years later stated: "Despite much empirical research, the psychology of religion field has made sadly little progress toward a comprehensive scientific understanding of religion" (Kirkpatrick 2006, p. 3). Spilka, that other champion of American empirical PoR and one of Hood's co-authors of Psychology of Religion, came to the same conclusion when taking stock of what psychological research had come up with regarding a specific religious phenomenon, prayer (Spilka and Ladd 2013). One might well suspect that among the reasons for general psychology's impressive quantitative growth are such as also prompted the many lamentations, from various sides, about the discipline's restricted value for a fundamental understanding of human beings, its loss of sight on the peculiarities of the individual, the nongeneralizability of its results obtained on middle class white students. In spite of (or perhaps because of) dealing with small-scale questions, concepts and manipulated variables, and in spite of its ever-increasing refinement of scales and sophisticated statistical techniques, psychology is being criticized for not observing sufficiently, not going deeply enough into the phenomena it wants to explore, especially when constructing its "measuring instruments". From different sides, efforts have been made (or at least called for) to develop approaches that allow psychologists to get in touch with human reality again, with first-hand experience and with the meaning that real conduct (as opposed to score on scales or on laboratory tests) has for human subjects (Belzen 1997a; Giorgi 1976).

\section{The Hoodian study of religion}

Such pleas to integrate methods other than quantitative-statistical methods into psychological research, also on religion (Belzen 1997b), have not been lost on Hood. Being interested in religious experience and its meaning to human subjects, he increasingly oriented himself to other types of research than those he started out with. As well as theoretical research, he grew interested in methods that are often called qualitative, applying them in studies on religious movements such the Snake Handlers and Pentecostal Churches, opening up in general to more hermeneutical approaches to empirical research (Poloma and Hood 2008; Hood and Williamson 2008). With some humor, one might well claim that he thereby established a genre all on his own: "the Hoodian study of religion," as sometimes he seemed to be overshooting the target. For a clear shift is visible in at least some of such later publications by Hood: they boldly employ a variety of other than standardized empirical methods, but hardly any longer from a psychological perspective. On the contrary, to the extent that they can count as psychological publications (as distinct from publications by a psychologist, a genre to which they sometimes lean too), they are accusing psychology of being reductionistic towards the religious phenomena under scrutiny. Hood proves himself well read in psychology here, but aiming to point out that the types of psychology he critiqued offer hardly anything when it comes to analysis of the religious phenomena he is investigating.

The issues raised here are quite fundamental: in an object psychology (such as the PoR), some type of psychology, developed for its own reason, is being applied to 
multiple objects (or sometimes entire fields, such as health, education, industry, and many others found in handbooks of applied psychology). A psychological analysis can never be the only tool for understanding something about a certain empirical phenomenon (be it an act of love or of crime, be it the onset of a war, an effort to improve the efficiency of teachers or salesmen, or whatever). To any embracing analysis, psychology will only add one specific, viz. a psychological, perspective (which may be multiple in itself, as so many types of psychology exist). Refraining from any restrictive definition of what psychology might be, but adopting a very open and integrative perspective toward this discipline, it will probably be uncontroversial to say that on the whole and in general, a psychological analysis of an empirical phenomenon will probe what, from a perspective of a certain psychological theory or with the aid of some specific psychological instrument, can be said about the phenomenon under scrutiny, even if this is commonly considered a religious phenomenon (such as conversion, prayer, snake-handling or an emerging Pentecostal Church, to remain with empirical examples mentioned already).

From a meta-perspective, Hood's remarkable effort to get closer to the reality of religious phenomena, to the lived experience of human subjects involved in them, has at least two aspects:

1. He is trying to take seriously what subjects themselves are claiming about their experiences.

2. In his denial of the appropriateness of existing psychological theories to analyze these experiences, he also requires psychology to first confirm and adopt the adequacy of subjects' claims (e.g., "God touched my soul"). From a methodological perspective, the first aspect is to be applauded: the effort to take seriously what human subjects report about themselves, to let them speak freely about their experiences and to resist to reduce their accounts to pre-existing psychological categories, is an approach all too seldom found in present psychological research aiming at operationalization, standardization, and quantification, judging employment of statistical analysis of measurements to be the highest standard in empirical research. (So, in this respect, Hood clearly opened up to other empirical approaches than in his earlier work on scale-construction.) With the second aspect, however, he seems to be violating the very first principle of any phenomenological analysis; namely, to suspend any verdict at the ontological level.

There are several concerns here. When someone testifies that "God touched my soul", there is no reason for anyone, psychologist or otherwise, to assume or reject the possibility of a substantive existence of a "soul" (that would perhaps survive the death of the body or whatever else has been claimed about "souls"). Rather, what needs to be done, in research, is to take the testimony seriously, try to understand, clarify, and describe its structure (if one wishes to work within, e.g., a phenomenological approach), try to detect and analyze its relationship to viewpoints as postulated in various psychological theories (if one wishes to proceed as a psychologist) or bring to bear viewpoints from sociology (if one wishes to proceed as a sociologist), etc.

Also, to be working and remain working within a scientific framework, there can be neither affirmation nor negation about "God" or about any reference to any realm beyond the empirical one. Contrary to all-too-common vulgarized thought, 
a scientific approach to religion does not prove or deny the existence of "God" or any supernatural being, it does not falsify or justify theological claims, it is only taking a limited perspective, from within the scientific approach a certain researcher has been trained in. There should be no need to dwell long on this issue, a reference to the early history of the PoR may suffice: as early as 1903, Théodore Flournoy (1854-1920), another founding father of psychology, described what he had noticed in the young science of the PoR: in their analyses, researchers do not refer to any transcendent realm, but rather restrict themselves to the application of their scientific knowledge (Flournoy 1903). It is like two sides of the same coin, really: within their scientific work, researchers "exclude transcendence," they will not call upon any kind of supernatural realm, deities, demons, or whatever, as agents in a possible explanation for the phenomena investigated; they will try to only make use of theories and categories specific to their science, a science that offers only a limited perspective for sure, but that is hopefully proven to be intersubjectively valid by rigid research. And the more general observation formulated above already applies here too: such research, whether on religion or not, does not employ "transcendence" as an explanation, but it neither denies "transcendence" nor affirms "transcendence." This position is often called "methodological agnosticism," for whatever a psychologist, or any scientist, may privately believe about anything transcending the common human realm, as a psychologist she or he knows nothing, remaining agnostic, for methodological reasons, during professional work. Simple as it sounds, this methodological agnosticism proves quite hard to practice: it is not so easy to suspend applying convictions often held so dearly as religious, metaphysical or ethical ones; the history of the PoR, in fact, the history of all "sciences of religions" is replete with examples of research confirming opinions that investigators held well before they set out. The role of a prioris in general being inevitable in scholarly work, the solution is not to try to deny them or keep them hidden, but rather to become conscious about them and to communicate them, inviting others to reflect and react, as practiced in real communication (Jaspers) and on a methodological level, analyzed by, among others, Gadamer (1960/1986).

Granted, "phenomenology" is a term used (and abused) in a variety of ways, and it certainly never just meant "description," as simplified contemporary parlance, especially in psychology, has it. Edmund Husserl (1859-1938), who introduced phenomenology to psychology, taught that in a psychological analysis, "phenomenological epochê" should be applied: anything other than a psychological reality (even the physical reality of an object perceived, let alone a "God") should be "put outside the brackets," should not be dealt with at all; the aim is to analyze how a certain phenomenon presents itself in the observer's consciousness. (Thus, even if we investigate persons telling us they experience "God", we never investigate "God," but only "persons telling us they experience God," we deal with their image of God, their conception of God, etc., leaving questions about the status and nature of any "God" beyond human representations of such a "God" to theologians such as Paul Tillich [1886-1965], who proposed in this context the phrase "God beyond God": Tillich 1952.) And despite all the flaws of so-called "phenomenology of religion" (e.g., Van der Leeuw 1963), phenomenology as it was practiced in this branch of scholarship equally strived to refrain from statements about the metaphysical aspects of religion, 
the "truth-value" of religions not being at stake in a scientific analysis. Science as such neither confirms nor opposes religion, it is speaking along other lines about other aspects of reality. In this respect, Hood is probably incorrect about psychology when stating that it "must [..] approach its object of study [..] within the framework of [an] object's own first principles" (Hood et al. 2005, p. 183), as a psychological investigation should not, to be psychology, adopt the "framework" of the persons studied. Taking the framework - or, for that matter, anything the subjects say-into account, psychology should proceed along psychological perspectives, that more often than not neither reiterate nor confirm the subject's perspective. (Otherwise, what would psychology add to a nonscientific description or articulation of, e.g., experience? By just repeating subjects' reports, one is not yet doing psychology.)

This is a very important issue, one that has played a role throughout the history of the PoR, in both the work of important participants in the field and in its reception by non-psychologists (e.g., theologians). Very often, the PoR is understood as psychological research on religion, ${ }^{1}$ it is the attempt to find out something about religion by means of psychology. Not all and everything psychological about religion counts as the PoR, however: a "psychological novel" in which religion is featured, for instance, does not count as PoR. (Also, the "psychological" novels published by Henry James do not qualify him as a psychologist, nor does the fact that his brother, William James, was one of the most famous psychologists.) It may be helpful here to remind of the old methodological distinction between the formal object and the material object of a science: the formal object distinguishes a specific scientific discipline that might be applied to a variety of material objects. The core of a science such as psychology is the development of valid psychological knowledge (commonly phrased by means of specific concepts and theories, published in media reserved for psychology). The knowledge, thus generated, may be applied in many other fields (health, education, industry, etc.) to which psychology always provides just a partial perspective. (The treatment of trauma, e.g., is not limited to psychologists; in matters of recruitment and hiring, experts other than psychologists also have their say, etc.) What distinguishes psychology is its formal object: even empirical topics that are often discussed by psychologists (such as emotions) are not restricted to psychology and can be studied from the formal object of other disciplines too (anthropologists, historians, biologists, geneticists, sociologists also conduct research on emotions). Granted, as the formal object of psychology is multiple, there are many kinds of psychology (Belzen 2019), but that does not invalidate

\footnotetext{
1 More generally, however, one might define the PoR as an attempt to deal with religion (in whichever way defined) in terms of psychology (in whichever way defined). This very general, more liberal circumscription allows for a very broad ecumenical understanding, acknowledging that work in the PoR has sometimes has been conducted by people trained in other disciplines such as sociology (e.g., Carroll 1986, 2002), psychiatry (e.g., Meissner 1992; Rizzuto 1979) or theology (e.g., Fowler 1981; Theißen 1983, 2007)—even the present editor of a journal such as The International Journal of Psychology of Religion does not have a background in psychology! - and that all kinds of practical psychological work, e.g., psychotherapy, may count as the PoR too, if religion is being treated in a professional psychological (as distinct from, e.g., a pastoral-theological) way (Belzen 2010a). Moreover, one should be aware that even such a broad understanding of the PoR constitutes just one element-perhaps not the most important one ... - of what is going on between the entities of religion and theology on the one hand and the science and practice of psychology on the other (Belzen 2010a, 2015).
} 
the point just made: obviously, some demarcation must be employed to distinguish psychology from non-psychology. A very open circumscription, in line with current thought in the philosophy of science (Belzen in press), may serve the present purpose: a piece of research will count only as psychological, not because anyone just calls it "psychological," but because it is conducted along the lines of one of the approaches accredited "at the forum," by the larger scholarly community (represented by, e.g., APA), when it is conducted by means of the theoretical, methodical, and analytical categories of some established psychology (therefore, usually published in a medium specific to psychology). Thus, writing personal documents such as letters does not as such qualify an individual as a psychologist, but such letters may become the object of analysis by a psychologist, see Allport (1965).

Although this may sound uncontroversial, it can be easily applied to the PoR: research on something considered religious (as a material object) will only count as psychological when conducted in a professional psychological way, i.e., along the lines of a certain type of (established, scientific) psychology. (Therefore, a diary relating an individual's upbringing will not count as scientific psychology, but it may become a type of data within a certain psychological investigation; or, to give an example from a religious realm: Teresa of Avila extensively describing her subjective experiences is not yet practicing psychology, but the resulting ego-document may well become an object in a piece of research in the PoR.) Tautological as it may sound, PoR is psychology, it is practiced along the lines of the Western enterprise called psychology. This means that the relationship of PoR to its mother discipline, psychology in all its variety - for psychology is plural, its nature contested-is essential to distinguish PoR as a separate field devoted to research on religion. In a number of Hood's later field studies (Hood et al. 2005; Hood and Williamson 2008; Poloma and Hood 2008), he not only moved away from the common standardized research methods used in psychology, he even discontinued employing psychology to analyze and interpret the data he so diligently gathered with a variety of other than standard psychological techniques. Note: Hood's procedure is not being criticized here, on the contrary, as will be tried to explained in a moment.

Moreover, his gradually moving to the margins of psychology is reflected in some of his present institutional affiliations: at the University of Chattanooga, where he has been employed for some 50 years, he is, as of 2016, also serving as a professor of religious studies. (For whatever he may or may not be doing in psychology, no one can doubt that he is working on religion!) And with Brill, a renowned Dutch publisher in the field of Theology and Religious Studies, he is now an editor of Research in the Social Scientific Study of Religion and of Brill Research Perspectives in Religion and Psychology. While obviously there is nothing wrong with these moves, it is also obvious that the chances of having an impact on psychology in this way are decreasing - and it is the latter, bringing research on religion back to psychology in general, that has for decades been a major motive of psychologists working on religion (Hood and Spilka 2012), who have often complained that their research would be discriminated against and therefore not published by psychology journals.

Also, what is not at stake here is any criticism of Hood's being clearly apologetic: he is defensive toward the movements and groups that he is describing. As such, 
this need not be a problem that invalidates any of his work: psychology usually serves extra-psychological goals, appointed by instances other than the science of psychology itself. Much psychological research has been commissioned by the Pentagon, e.g., and by some kind of industrial business or by supporters of values that in and by themselves are not yet psychological, such as the promotion of health or human welfare. While in the West, some churches have called for and facilitated the establishment of a subdiscipline such as pastoral psychology, intending to serve the Christian ministry (Klessmann 2004; Watts et al. 2002), in the formerly Communist Eastern Europe, psychologists were employed at scientific institutions, established with the goal of conducting research in order to find out how to destroy religion (Kääriäinen 1989). Science itself is blind, it is always led by extra-scientific goals. And on a personal level, psychologists of religion obviously have their private, nonprofessional opinions about (things considered to be) religion. Absolute neutrality being unachievable, as long as psychologists do not present their private opinions as infallible scientific statements, not too much can go wrong.

Like any other sciences, psychology cannot tell whether and which religion is either right or wrong, it cannot tell which religion is the "best." Contrary to the trend in many Western societies to have psychologists decide, or at least grant them authority, on matters that used to be addressed by philosophers or religionists (be it courting, raising children, respecting others, in general, in questions about how to live), psychologists as psychologists cannot go beyond their disciplinary limits when turning to religion. To give only one simple, probably meanwhile uncontroversial example: some psychologists of religion, formerly trained as Roman Catholic priests, have become furious with their Church because of the obligation of celibacy, and would have liked to "prove" by means of psychological research how unhealthy such a practice is (McCarthy 2014). But even if they could have proven this (which was not the case!), it still may be the case that higher values than the ones psychology usually serves (e.g., mental health, wellbeing) override any psychological verdict. For religious reasons, an individual or an entire society may adhere to practicing $\mathrm{x}$ or $\mathrm{y}$, but it is not for psychology to prescribe whether they should do so or not. Psychology can investigate psychological antecedents, character, and consequences of affirming the value of $\mathrm{x}$ or $\mathrm{y}$ (be it celibacy, temple prostitution, martyrdom, flagellation, etc., in the religious realm), but cannot prescribe or prohibit any of them; psychology can, however, contribute to clarification of the nature of such practices, helping others to make their decisions (e.g., to practice celibacy or not). Martyrdom obviously is damaging to health, but may for religious reasons-which a believer may consider more important than medical or psychological reasons-nevertheless be a preferred option.

Therefore, Hood trying to understand phenomena such as snake handling or Pentecostalism (religious phenomena, according to their practitioners) is correct when he opposes efforts to only criticize or even vulgarize them from a psychological perspective. Two things seem puzzling in this regard, however:

1. As noted, in much of his recent work, Hood left psychological analysis behind (or only discussed it in order to reject it). Understandable as this may be, one may wonder why he persists in calling it psychology. 
2. The treatment of some of the empirical religious phenomena he selected, however, may perhaps be not only no longer psychological itself but it also seems unbalanced. It is positive, even defensive, as already noted by others (Kane 2010; Wulff 2006). When discussing this, e.g., at conferences, Hood admitted that a phenomenon such as snake handling certainly has, in his own words, "a dark side," and he announced that he would address this in a next publication as well; with the book Them that believe he first of all wanted to have painted a positive picture (Hood and Williamson 2008). It is curious that he has not yet published on that dark side, as preventing an all too apologetic reputation would have been required.

\section{From James to Hood}

Discomfort and impatience with psychological analysis of religion, sometimes implicitly, sometimes explicitly, as found with Hood, is all too understandable, however. And his alternative, viz. to move beyond or at least up to the margin of psychology in order to get closer to an empirical phenomenon by means of sometimes radically different methods than those used in contemporary mainstream psychology has famous forerunners, even beginning with William James (1842-1910), another American founding father whom Hood so strongly resembles, although in a different way than is the case with Hall.

To many, raising questions about aspects of James' work as a psychologist of religion may seem a sacrilege, but is it really? The reply that James was no less than the founding father of the PoR is understandable-but is it correct? For well over a century now, James' deservedly famous Varieties of Religious Experience (VRE 1902/2002) has been a kind of bestseller and it for sure has gained the PoR many supporters. But was it a work in the PoR? James no doubt belonged to the founding fathers of the enterprise at present called psychology. Trained in, among other disciplines, medicine and philosophy, he published a two-volume work that was one of the instigators of the present field: The Principles of Psychology (PP 1890). But does that mean that all that James published was psychology? Or that since 1890 he published only psychological works? James himself certainly did not see things this way. In the VRE, he clearly states that his intention is to publish a philosophical work on religion. Empirically informed as to his opinion philosophy should be, he for some years collected data reporting religious experiences, which he decided to publish as a kind of prolegomena to his philosophy of religion. In these prolegomena, James concluded that what is commonly called "religious experience" is in fact better referred to as "varieties of religious experience." Advocating an empirical perspective, James rejected the idea of one, single religious experience; religious experience is plural, exists in a multitude of forms - something that needs to be acknowledged in a philosophy of religion from the onset, according to James. Besides, and importantly, there is no relation between what James tried to achieve in psychology and in his VRE: in no way is he employing concepts or theories from PP to his exposé of descriptions of religious experiences, nor is he drawing conclusions about religious experiences from the perspective of any other psychological work. 
To conclude against James' own opinion that the VRE would be a psychology of religion seems odd. Another, a better conclusion is possible: James, who certainly belonged to the first psychologists of religion, was not so much interested in applying the psychology of his day to the study of religion, but was far more interested in religious experiences as such and tried to get as best as possible an empirical perspective on these phenomena. As the psychology of his day, according to him, did not yet allow him to achieve this goal, he proceeded in a different way, without psychology. Throughout the history of the field, up to Hood, noted psychologists of religion have gone down that same path, leaving their profession behind in order to get much closer to living religious reality than psychological theories and methods allow. To give just some examples from Europe, both not sufficiently known in the USA: in the early days, Wilhelm Stählin (1883-1975), initiator of experimental research in the PoR, moved over to phenomenology; in more recent times, Antoine Vergote (1921-2013), grand old man of post WW II European PoR, on retirement having left obligations in PoR behind, continued to finish elaborate works in philosophy and in theoretical psychoanalysis (Belzen 2015).

This lack of relevance, as this last paradox might be called, has even been eloquently formulated in The International Journal for the Psychology of Religion cofounded by Hood (e.g., Nørager 1996). When a few years ago, Hood and Spilka (2012) depicted the renewed acceptance of the PoR within psychology in general as a major achievement, the editor of that special issue of Religious Studies and Theology on PoR, himself a psychologist and a specialist on phenomenology, asked whether PoR's “indistinguishability from psychology is not so much an achievement, but merely recognition of the muddledness that characterizes both; do we have an inclusive pluralism, or merely an indifferent cacophony? 'Diversity' or chaos? A 'rich abundance' or a compulsive productivity?” (Peet 2012, p. 122) Indeed, in empirical research, PoR has mainly dealt with students at Western universities as subjects, rarely ever trying to directly approach religious phenomena such as flagellation, fasting, or vocation. (See how little the PoR had to offer on the happenings of 9/11 and how little we can say about religious terrorism, even today.) For better or for worse, psychologists tend to continue along the lines of their predecessors, receding ever more from lived reality, adopting scores on questionnaires, etc., as their primary data. This is understandable, as adapting to mainstream psychology facilitates publishing in psychology journals not restricted to the study of religion (something rarely found with the later Hood), but it is also understandable that the very "customers" of the PoR, such as religionists and theologians, grow disappointed. In this respect, one should be alarmed by the notable differences between responses toward the (possible) PoR a century ago and at present. Shortly after 1900, expectations regarding PoR were high, sometimes also fearful, but at least there was reaction and involvement, and at a number of institutions for Theology, or later called Religious Studies, positions for PoR were established. At present, however, despite the impressive quantitative growth of publications in the PoR, most of this has been lost, and PoR gets hardly any attention. (Sociology of Religion seems to have been better able to maintain the attention of Theology and Religious Studies, where, beyond some psychoanalytic perspectives, not much of the present empirical PoR is found.) 


\section{Final words}

These all too brief comments do not intend to criticize anything or anyone: they articulate concern. It may well be that past expectations regarding PoR have been unrealistic and that the present situation is more in balance than previous ones. But it may also indicate that the recent growth of PoR is mainly an epiphenomenon to the expansion of psychology more generally. Be this as it may, the paradoxical lack of unity, progress, and relevance haunting psychology should not be downplayed, as their consequences are important, and, in the present paper, help to situate and explain Hood's proceeding differently than along the lines of psychology at large. Hood has forcefully and repeatedly demanded that the PoR must remain in touch (or get in touch again) with religion itself. If he means to suggest that the PoR should affirm religious reality (even if only in statements by religious subjects), or that its proponents should refrain from applying scientific instruments such as psychological concepts or categories, Hood is clearly wrong. But when his demand implies that there should be, by whatever means, a serious effort to not reduce religious phenomena to whatever standardized psychological techniques allow for, he is clearly correct: psychologists of religion would do wise to incorporate additional perspectives and methods that allow us to explicate the psychological aspects of the meaning that a certain religious form of life has to its participants. And when Hood calls for a dialog with religionists, or with their academic spokesmen such as theologians and with religious leaders, he is probably right again, for just starting from any psychological method or theory and applying it to a religious sample does not enhance the relevance of the PoR, a goal probably better reached by proceeding from a religious phenomenon and trying to interpret the psychological aspects of its meaning to its practitioners (Belzen in press).

Reflecting on the work of such an eminent representative of the PoR such as Hood presents a number of paradoxes. Referring back to the last one only, perhaps we are dealing with an inevitable dilemma here, as we can expect that the Scylla of striving to resemble contemporary psychology and the Charybdis of getting as close as possible to the reality being investigated will remain with us for quite some time. Perhaps the dilemma is given with the very existence of the PoR itself: it must be and remain (!) psychology, but it must also be (and become?) psychology of religion. Between Scylla and Charybdis, Hood has steered his own particular course, which may well become a beacon to future psychologists of religion.

Acknowledgements I thank Joseph Corveleyn, Vassilis Saroglou, Paul Williamson, and Hessel Zondag for discussions of earlier versions of this paper.

Funding Open access funding provided by University of Amsterdam.

Open Access This article is licensed under a Creative Commons Attribution 4.0 International License, which permits use, sharing, adaptation, distribution and reproduction in any medium or format, as long as you give appropriate credit to the original author(s) and the source, provide a link to the Creative Commons licence, and indicate if changes were made. The images or other third party material in this article are included in the article's Creative Commons licence, unless indicated otherwise in a credit line to the material. If material is not included in the article's Creative Commons licence and your intended use is not permitted by statutory regulation or exceeds the permitted use, you will need to obtain permission directly 
from the copyright holder. To view a copy of this licence, visit http://creativecommons.org/licenses/by/4. $0 /$.

\section{References}

Allport, G.W. 1965. Letters from Jenny. New York: Harcourt, Brace.

Belzen, J.A. 1997a. The historicocultural approach in the psychology of religion: perspectives for interdisciplinary research. Journal for the Scientific Study of Religion 36(3):358-371.

Belzen, J.A. (ed.). 1997b. Hermeneutical approaches in psychology of religion. Amsterdam: Rodopi.

Belzen, J.A. 2010a. Towards cultural psychology of religion: principles, approaches, applications. Dordrecht/Heidelberg/London/New York: Springer.

Belzen, J.A. 2010b. To read and to be read-The problematic nature of communication. Comment to comments. Mental Health, Religion and Culture 13:417-436.

Belzen, J.A. 2015. Religionspsychologie. Eine historische Analyse im Spiegel der Internationalen Gesellschaft. Heidelberg: Springer. Psychology of Religion. A historical analysis as mirrored by its International Association.

Belzen, J.A. 2019. What, why and how? Meta-reflections on cultural psychological approaches to the scientific study of phenomena called religious. Integrative Psychological \& Behavioral Science 53:158-187.

Belzen, J.A., and R.W. Hood. 2006. Methodological issues in the psychology of religion: towards another paradigm? Journal of Psychology 140:5-28.

Belzen, J.A., and A.J.R. Uleyn. 1992. What is real? Speculations on Ralph W. Hood's implicit epistemology and theology. The International Journal for the psychology of religion 2:165-169.

Belzen, J.A. in press. Die Dialektik des Salto mortale. Anmerkungen zu Schwierigkeiten, Möglichkeiten und Notwendigkeiten im Dialog zwischen Theologie und Psychologie aus der Sicht der Religionspsychologie. In Die Entdeckung der inneren Welt, ed. A. Haußmann, Peter Schüz, and Niklas Schleicher, $\mathrm{xx}-\mathrm{xx}$. Tübingen: Mohr-Siebeck. The dialectics of salto mortale. Notes on difficulties, possibilities and necessities in the dialogue between theology and psychology from the perspective of psychology of religion. In: The discovery of the inner world.

Bühler, K. 1927. Die Krise der Psychologie. Jena: Fischer. The crisis in psychology.

Carroll, M.P. 1986. The cult of the Virgin Mary: psychological origins. Princeton: Princeton University Press.

Carroll, M.P. 2002. The penitente brotherhood. Patriarchy and hispano-catholicism in New Mexico. Baltimore/London: Johns Hopkins University Press.

Dittes, J.E. 1969. Psychology of religion. In The handbook of social psychology, 2nd edn., Vol. 5, ed. G. Lindzey, E. Aronson, 602-659. Reading: Addison-Wesley.

Flournoy, T. 1903. Les principes de la psychologie religieuse. Archives de Psychologie 2:33-57.

Fowler, J.W. 1981. Stages of faith: the psychology of human development and the quest for meaning. San Francisco: Harper \& Row.

Gadamer, H.-G. 1986. Truth and method. New York: Crossroad.

Gibson, J.J. 1985. Conclusions from a century of research on sense perception. In A century of psychology as a science, ed. S. Koch, D.E. Leary, 224-230. New York: McGraw-Hill.

Giorgi, A. 1976. Phenomenology and the foundations of psychology. In Conceptual foundations of psychology: Nebraska symposium on motivation, 1975, ed. W.J. Arnold, 281-408. Lincoln/London: University of Nebraska Press.

Gleitman, H. 1985. Some trends in the study of cognition. In A century of psychology as science, ed. S. Koch, D.E. Leary, 420-436. New York: McGraw-Hill.

Hall, G.S. 1882. The moral and religious training of children. Princeton Review 10:26-48.

Hall, G.S. 1904. Adolescence: its psychology and its relations to physiology, anthropology, sociology, sex, crime, religion, and education. 2 vols.. New York: Appleton.

Hall, G.S. 1917. Jesus, the Christ, in the light of psychology. New York: Doubleday.

Hood, R.W., Jr.. 1968. An empirical test of the validity of Rokeach's Opinionation Scale. Journal of Psychology 69(1):47-52.

Hood, R.W., Jr.. 1973. Psychology of religion: the search for appropriate psychological theories. In Book of abstracts, ed. R.W. Hood Jr.. San Francisco: The Society for the Scientific Study of Religion in conjunction with Religious Research Association.

Hood, R.W., Jr.. 1975. The construction and preliminary validation of a measure of reported mystical experience. Journal for the Scientific Study of Religion 14:29-41. 
Hood, R.W. 1997. The empirical study of mysticism. Retrospective and prospective. In Taking a step back. Assessments of the psychology of religion, ed. J.A. Belzen, O. Wikstrom, 111-126. Uppsala: Acta Universitatis Uppsaliensis.

Hood, R.W., Jr.. 2002. Dimensions of mystical experiences: empirical studies and psychological links. Amsterdam/Atlanta: Rodopi.

Hood, R.W., Jr.. 2003. Conceptual and empirical consequences of the unity thesis. In Mysticism: some psychological considerations, ed. J. Belzen, 17-54. Amsterdam/Atlanta: Rodopi.

Hood, R.W. 2010. "Towards cultural psychology of religion: principles, approaches and applications": an appreciative response to Belzen's invitation. Mental Health, Religion and Culture 13:4397-4406.

Hood, R.W. 2012. Psychology of religion: a personal narrative. In Psychology of religion: autobiographical accounts, ed. J.A. Belzen, 107-131. New York: Springer.

Hood, R.W., and J.A. Belzen. 2005. Research methods in the psychology of religion. In Handbook of the psychology of religion and spirituality, ed. R. Paloutzian, C. Park, 62-79. New York/London: Guilford.

Hood, R.W., and J.A. Belzen. 2013. Research methods in the psychology of religion and spirituality. In Handbook of the psychology of religion and spirituality, 2nd edn., ed. R.F. Paloutzian, C.L. Park, 75-93. New York/London: Guilford.

Hood, R.W., and B. Spilka. 2012. A chronological overview of the psychology of religion. Religious Studies and Theology 31:129-146.

Hood, R.W., Jr., and P.W. Williamson. 2008. Them that believe: the power and meaning of the Christian serpent-handling tradition. Berkeley: University of California Press.

Hood, R.W., Jr., P.C. Hill, and W.P. Williamson. 2005. The psychology of religious fundamentalism. New York: Guilford.

Hood, R.W., Jr., H. Streib, B. Keller, and C. Klein. 2016. The contribution of the study of "spirituality" to the psychology of religion: conclusions and future prospects. In Semantics and psychology of spirituality: a cross-cultural analysis comparing Germany and America, ed. H. Streib, R.W. Hood Jr., 459-469. New York: Springer.

Hood, R.W., Jr., P.C. Hill, and B. Spilka. 2018. The psychology of religion: an empirical approach, 5th edn., New York: Guilford.

James, W. 1890. The principles of psychology. London: MacMillan.

James, W. 2002. The varieties of religious experience: a study in human nature. London/New York: Routledge.

Jaspers, K. 1973. Philosophie II: Existenzerhellung. Berlin/Heidelberg/New York: Springer. Philosophy, vol. II: Illumination of existence.

Kääriäinen, K. 1989. Discussion on scientific atheism as a soviet science, 1960-1985. Helsinki: Suomalainen Tiedeakatemia.

Kane, S.M. 2010. Review of Hood \& Williamson (2008), Them that believe. The International Journal for the Psychology of Religion 20:69-71.

Kirkpatrick, L.A. 2006. Precis: Attachment, evolution, and the psychology of religion. Archiv für Religionspsychologie 28:3-47.

Klessmann, M. 2004. Pastoralpsychologie. Neukirchen: Neukirchener Verlag. Pastoral psychology.

Krauss, S.W., and R.W. Hood Jr.. 2013. A new approach to religious orientation: the commitment-reflectivity circumplex. Amsterdam/Atlanta: Rodopi.

McCarthy, T. 2014. The called, the chosen, and the tempted: psychologists, the church, and the scandal. American Catholic Studies 125(4):1-49.

Meissner, W.W. 1992. Ignatius of Loyola: the psychology of a saint. New Haven: Yale University Press.

Nietzsche, F. 1980. Die fröhliche Wissenschaft. München/Berlin/New York: De Gruyter. The joyful science.

Nørager, T. 1996. Metapsychology and discourse: a note on some neglected issues in the psychology of religion. The International Journal for the Psychology of Religion 6:139-149.

Peet, C. 2012. Psychology of religion. Religious Studies and Theology 31:111-127.

Poloma, M., and R.W. Hood Jr. 2008. Blood and fire: godly love in a Pentecostal emerging church. New York: New York University Press.

Rizzuto, A.M. 1979. The birth of the living god: a psychoanalytic study. Chicago: University of Chicago Press.

Saroglou, V. 2020. The psychology of religion. London/New York: Routledge.

Spilka, B., and K.L. Ladd. 2013. The psychology of prayer: a scientific approach. New York/London: Guilford. 
Spilka, B., R.W. Hood, and R.L. Gorsuch. 1985. The psychology of religion: an empirical approach. Englewood Cliffs: Prentice Hall.

Stace, W.T. (1960). Mysticism and philosophy. London: MacMillan.

Theißen, G. 1983. Psychologische Aspekte paulinischer Theologie. Göttingen: Vandenhoeck \& Ruprecht. Psychological aspects of Pauline theology.

Theißen, G. 2007. Erleben und Verhalten der ersten Christen. Eine Psychologie des Urchristentums. Gütersloh: Gütersloher Verlagshaus. Experiences and conduct of the first Christians. A psychology of early Christianity.

Tillich, P. 1952. The courage to be. New Haven: Yale University Press.

Van der Leeuw, G. 1963. Religion in essence and manifestation: a study in phenomenology. New York: Harper \& Row.

Watts, F., R. Nye, and S. Savage. 2002. Psychology for Christian ministry. London/New York: Routledge.

Wulff, D.M. 2006. Review of Hood et al. (2005), The psychology of religious fundamentalism. Journal for the Scientific Study of Religion 45:298-300.

Zimbardo, P. 2004. Does psychology make a significant difference in our lives? American Psychologist 59:339-351. 